\title{
Knowledge in Motion: Highly-Skilled Migration and the Role of Regional Networks ${ }^{1}$
}

\author{
Alexandra David (PhD) \\ Institute for Work and Technology, \\ Westphalian University (Germany) \\ Frans Coenen (PhD) \\ University of Twente (The Netherlands)
}

\begin{abstract}
This study gives insights into the performance of actor networks in the identification of human capital in form of highly-skilled immigrants and the development and implementation of human capital strategies for this target group, esp. The consideration of multiple actor networks as co-creators and co-producers of a regional human capital agenda focussing on highly-skilled immigrants is a contribution to regional human capital development. Hereby, actors' networks were studied as a regional resource based on regional social capital. Especially actor networks, which are not primarily created for human capital development, such as alumni networks, are here discussed as innovative actors in the development of bottom-up strategies to attract and bind highly-skilled immigrants.
\end{abstract}

\section{BACKGROUND}

The discussion on skills shortage, regional knowledge flows, innovativeness and highly-skilled migration has faded a little into the background in the last few years. But, the newest refugee immigration to Western European countries between 2015-2017 fuelled again the overall debate on immigrants as potentials for regional economies. Facing the problems of the past years of labour market integration of refugee immigrants in Western Europe (David et al., 2019; David \& Coenen, 2017) and the challenges around the recognition of qualification degrees, (David et al., 2019), the debate (re)turns to its main quest:

It demands a specific kind of human capital and knowledge from immigrants to assure sustainable and innovative regional economies and tries to identify new ways of attraction to get there.

This article deals with the overall problem experienced by many European regions, lacking (adequate) regional human capital in specific sectors such as e.g. care, IT or crafts, which is also regarded as a major societal challenge by national and EU political and social actors (David, 2015). The problematic issue of a lack of (adequate) regional human capital as relevant to regional socio-economic development is underlined by several academic studies. An overview of interdisciplinary research in the field of innovation and knowledge, indicates that highly skilled are the main knowledge carriers and needed for regional economic development and innovativeness, as they empower knowledge to circulate between places (compare for instance

1 The current article is based on the theoretical framework of the thesis: David, A. (2015): Human Capital and the Role of Networks - Migration, Inclusion and New Qualification for A Sustainable Regional Economy. University of Twente. 
David, 2015; Cohen \& Levinthal, 1990; Growe, 2009; Faggian \& McCann, 2009; Trippl \& Maier, 2007). At the same time, they form the backbone of regional societies (compare for instance Stockhorst, 2011; Fikkers, 2005) building a solid regional knowledge base. In times of internationalisation, digitalisation and new economic demands the regional human capital stock is reliant on external knowledge inflows from abroad in form of highly-skilled immigrant employees. These individuals are the target group regions and their companies want to attract. In the following the explanation for this will be given.

Additionally, Europe is facing other social challenges related to the problem of lacking (adequate) regional human capital. One is the aging European population. Even if the immigration flows of the latest years could counteract this development a bit, still it is a challenge, especially for rural regions or regions cross-bordering European countries to "rejuvenate".

Likewise, latest events showed that immigration processes are still ongoing within Europe (in the form of free movement of workers within Europe) and to Europe from overseas (David et al., 2019). And also the newest Brexit developments (David \& Barwińska-Małajowicz, 2018) will probably influence migration processes especially concerning the EU-immigrants which will turn their back on the UK and change direction to further countries such as the Netherlands and Germany; but still, the overall changing European immigration policies becoming more restrictive, counteract attraction activities to gain new highly-skilled immigrant employees.

Also, the experiences and the public-driven discussions of the last three years show, that especially immigrating people from oversees and the new generations of EU-immigrants are not always the one matching exactly companies' expectations. (David et al., 2018). Labour market disequilibria, high unemployment rates among the incoming groups in several European regions as well as a high competition between EU-immigrants, refugees and longterm unemployed hometown residents are the results (David et al., 2019; David \& BarwińskaMałajowicz, 2018). The current picture shows that on the one hand there is a skills shortage in several European regions, especially related to knowledge-based sectors such as IT, and service-based sectors such as handcrafts and the health/care sectors (David et al., 2018). While on the other hand, there is much untapped potential in form of immigrants, which is not being involved to its full extent, also because of cultural differences, no exact skills identification and diverse habitus towards working cultures and several professions (David et al., 2019).

These socio-economic challenges point even more to the demand for highly skilled and their specific knowledge, which will accelerate in future times. Under the term "New Work" futurologists discuss the scenario that stronger digital development in the context of working conditions will change our work habits and the paradigm towards more humanity. Modelling a future scenario, highly skilled would be the one developing new business models and following their vocation instead of "just having a job" and therefore being the forerunners of working societies. Herewith, their importance for social transitions is indisputable.

There is still a backlog on national and regional agendas, including policies and strategies based on existing mechanisms to assure activities targeting the attraction of highly-skilled immigrants.

Given this societal problem, this paper attempts to provide insights into and understand the mechanisms and conditions underlying regional human capital strategies focussing the group of highly-skilled immigrants, in order to develop and implement them. An insight into the 
mechanisms related to human capital and understanding them is relevant in the context of strategy development and its implementation, because identifying these mechanisms and understanding them allows regions to act. The mechanisms can be quite different (causal) relations in society. For instance, the relation between personal preferences and migration motives, the relation between internal knowledge types and external knowledge flows, or the relation between the mobilisation and motivation of untapped labour potential.

Measures address a specific mechanism, such as addressing particular personal preferences or the curricula in education systems. If a particular human capital related mechanism is not relevant in a certain region, for instance if there are no immigration flows, there is no basis or possibility to develop strategies. Following this line of argument, the development and implementation of human capital strategies for highly-skilled immigrants are regional choices, depending on the presence and/or absence of human capital related mechanisms. In this paper the following human capital related mechanisms were taken into closer consideration: immigration and return migration behaviour (brain flow), including motives for migration decisions according to push and pull factors, new migration patterns and their related knowledge flows, the living and working conditions and choices of highly-skilled immigrant workers, the openness of region for highly skilled (re)-attraction. The role of networks and how they can contribute to the development of a highly-skilled immigrants human capital agenda will be discussed in the following.

\section{THE IMPORTANCE OF KNOWLEDGE RELATED TO HIGHLY SKILLED}

The definition of highly skilled is far more complex than the definition of human capital in general. Following Mohr (1997), human capital is defined as the performance potential of humans represented by qualified and (highly)-skilled individuals as prospective employees (Mohr, 1997). Thus, human capital is the collective regional potential articulated in the human knowledge base and reflected in human labour and skills. Referring to this definition, the characterization of highly skilled is no easy endeavour. This can be accounted for by the different approaches to highly skilled in manifold contexts and disciplines in which the term is used. None of the approaches can be marked as the right one, as they are all constituted by their own logic and functionality. In current times, the term highly skilled is often used in the debate on brain drain/brain gain and migration issues. The national or regional loss or gain of highly-skilled workers in terms of migrations processes is discussed according to this concept.

The term highly-skilled worker and in the context of migration, highly-skilled immigrant, is related to knowledge and the knowledge-based economy. Thus, in the broader literature, highly skilled are also termed "knowledge workers" (Drucker, 1969), "talents" (Florida, 2002), "carriers of knowledge/knowledge spillover agents" (Trippl \& Maier, 2007) or "knowledge holders" (Growe, 2009).

"Most commentary on the highly skilled assumes them to have a tertiary educational qualification or its equivalent. However, many graduates are not in highly-skilled jobs; conversely, many whose work is highly-skilled are not graduates." (Salt, 1997: 5)

In line with Salt (1997), it seems narrow minded to define highly skilled only in terms of their education or qualifications. If one does so, the term would need to be redefined from highly skilled to highly educated or highly qualified workers, the difference being that a higher degree or a tertiary qualification is not a guarantee that the holder is highly skilled. An individual who is highly educated or highly qualified is often found in positions which are beneath her/his qualification level. By contrast contrary, in several European countries (see Germany as an example) there is a demand for a "skilled/qualified workforce" (in German "qualifizierte Arbeitnehmer"), graduated after "dual vocational training" (duale Ausbildung), which is more 
adequate for their job positions than a tertiary education. Sticking to the education level to which highly skilled workers are related, one needs to take into consideration that the education systems within Europe are still uneven. This finds prominent reflection in the difficulty of recognising qualifications around Europe in the case of free movement or migration of highly skilled workers. The problem occurs on an even bigger scale when leaving Europe and regarding the challenge globally. As a consequence, highly skilled workers cannot be defined solely by their education or qualification level.

Often, the literature defines highly skilled in terms of academics or scientists or individuals provided with special talents and creativity (Florida, 2008; Trippl \& Maier, 2007). Stockhorst (2011) provides a differentiated view of highly skilled individuals, based on their abilities. Thus, he uncouples the notion from certificates and degrees, but assesses staff with regard to the scope of activities actually performed in a job. In doing so, Stockhorst (2011) pleads for a new classification of highly skilled. He also counts employees without a tertiary education under this term. Thereby he adds an important aspect to the discussion on the use of the recognition of qualifications of immigrants. In addition, such a view of highly skilled allows individuals without a higher education to be characterised as such. Definitely, highly skilled are people who hold knowledge in motion.

\section{Knowledge in Motion}

However, knowledge, which is solely circulated regionally, can lead to negative effects and, in adverse cases, to regional lock-ins. Based on this, Malmberg \& Power (2005) stress the importance of external knowledge to regions and their innovative performance. They consider a continuous entry of external knowledge an essential precondition for a region's competitiveness and economic growth (Malmberg \& Power, 2005; Butzin, 2000). Correspondingly, Martin and Sunley (2006) argue that the absence of external knowledge can bring regions into difficulty and make them inflexible in their actions and developments. Likewise, several regional sectors rely on varieties of knowledge, which are not provided by the regional knowledge base. According to Smed Olsen et al. (2010) there are four main channels which seem to be appropriate to transfer knowledge inter-regionally and within a firm. Apart from such events as conferences, firm-level interactions and the acquisition of codified knowledge from the literature, the authors suggest job-related migration (mobility) as a knowledge exchange channel. Similarly, Faggian and McCann (2009) regard human capital migration as a recognized option to enhance the external knowledge inflow and knowledge exchange, in general.

Connected to this suggestion, in recent times the discussion of highly-skilled migration was led by concepts popular under the terms brain drain/brain gain and brain exchange. In this context Saxenian (2007) works with the term "brain circulation". Brain exchange and brain circulation describe a knowledge exchange through the returning migrants e.g. via migration and/or transnational networks (Pries, 2001). These concepts became even more fashionable in times of the knowledge-based societies and economies, when it was recognised that the loss or gain of highly skilled by migration flows can determine regional sustainable socio-economic development. "Brain exchange implies a two-way flow of expertise between origin and destination. Where the net flow is heavily in one direction, the terms "brain gain" or "brain drain" tend to be used" (Salt, 1997: 5). The term brain drain was mentioned as early as the 1960s, referring first of all to migration flows between developing countries and industrialised ones (Dankwart \& David, 2011). Today, brain drain is also a common phenomenon across European regional borders. It is related to the European challenges such as high (youth) unemployment rate in several southeast European regions and the persistent income 
differences. Brain gain is an opposite phenomenon to describe the gain of highly-skilled workers, who often fill the regional skills shortage gap.

The (return) migration of highly-skilled workers can be profitable for regions in terms of knowledge spillover effects, especially when ex-emigré highly-skilled workers return to the domestic region or in case of a brain flow (referring to a circular migration). Concepts such as Saxenian's (2007) "New Argonauts" describe the process of highly-skilled migration between developing and industrialised countries. It stresses the high impact of highly-skilled immigration on national economies. In this article, this concept is transformed to the regional level. Highly-skilled migrants move abroad. Mainly, as the concept of "Expatriates" by Israel (2006) shows, Expatriates migrate in a professional context. In doing so, they take part in inter-regional firm exchanges or move internationally and inter-regionally to study. Highlyskilled workers who leave their native country and become part of the foreign society of the destination country or region acquire numerous skills during their stay abroad. First, they get in touch with foreign, often different cultures, which expands their intercultural skills. Moreover, they are often confronted with new ways of working in organisations and labour processes, and approach a new way of solution-oriented thinking. Apart from socio-economic abilities, highly skilled workers acquire personal knowledge, which relates to their new living situation. Often they are confronted with the challenges of a foreign environment, which they have to overcome. The acquisition of a new language and the expansion of a secondary "business language" such as English are common occurrences. In case of a successful incorporation in the new environment, highly skilled workers grow according to their capacities; in the best case they become global citizens.

The decision to undertake a return migration presents several success stories. Klagge and Klein-Hitpaß (2010) show how effective the inflow of external knowledge can work out in domestic economies. When returning to their domestic regions, highly skilled often go into business for themselves. They mix the newly acquired skills with the knowledge of their domestic region and, in doing so, engender innovative ideas. Return migrants' entrepreneurships (David \& Coenen, 2017) are often more successful than previously established ones. This can be reduced to the phenomenon described above (Saxenian, 2007). They use the knowledge and skills of both regions, mix them, and move forward faster. Sometimes, they open up a business they have witnessed in the foreign regions and adapt it to the circumstances of their domestic region. Moreover, highly-skilled migrants are habitually interlinked in several communities and actor networks. These so-called migration networks today are transnational in nature. Transnational networks not only concentrate on two-way co-operation between parties, such as the domestic and the receiving regions or countries, but on the domestic region/country and several receiving regions/countries. Actors in further regions, in which the highly-skilled worker was not directly involved, can also share such a community and enrich it. Such further relations in a network that relies on second-hand contacts are called the "weak ties" of a network: the person I know personally knows another, whom I don't yet know personally, but I can trust him to co-operate, because of the involvement of an intermediary person, who is one both I and he knows (Granovetter, 1973). This can be accounted for by the fact that highly-skilled workers are mostly employed for globally active companies and work in an international environment. In addition, the new migration patterns, such as "New Nomads" (David et al. 2012), describe the migration of highly skilled between their domestic region and not just one, but several destination regions. In thus migrating, the "New Nomads" spin a transnational network of brains that exchange knowledge. After their return to the domestic region, the network exists further due to new communication technologies. These so-called (knowledge) networks are not focused on location, but operate in a third dimension, which Bhabha (2000) calls the "third space". 
The operation of highly skilled in the third space means the usage of an exchange platform, where transmigrants accumulate knowledge and generate new knowledge by transnational interactions. Transforming this external knowledge flows into regional grounds and physical places such as regions can contribute to regional knowledge bases and regional innovative actions.

\section{Regional Human and Social Capital}

In general, knowledge is not an independent entity. In the sense of its generation, distribution and practical usage it is always coupled to human beings, who practice learning (as a means of gaining knowledge) at several levels (Hassing \& Klaerding, 2012; Trippl \& Maier, 2007) and exchange their knowledge with others, often within (knowledge-related) networks. This implies that there are varieties of knowledge which are regarded as "common property", distributed to audiences in the form of research papers, books, conferences, workshops and, in times of new media, also via internet and social networks, etc. This kind of knowledge is often known as codified or explicit knowledge, which can be transferred in time and space using language, codes and images (Cooke, 1996). In a broader sense, this knowledge can be regarded as part of regional social capital, which Coleman (1990) calls group-level social capital. By group-level social capital, Coleman (1990) and, in line with him, Boshuizen (2009), define social capital not as being driven solely by individual interests and goals and independent actions, but rather as bound by a social system, which combines individual actions and interests to a whole social occurrence. Transforming this line of argumentation to the action of knowledge generation and exchange by highly skilled as part of the regional human capital, it can be considered as regional social capital. Thus, knowledge is an individual and at the same time a common regional resource. The transition of codified knowledge is rooted in the whole educational system, starting with the primary school and continuing through all levels up to tertiary education, based on experience and knowledge as "common property". Finally, the LLL concept is no different, including as it does formal and informal learning opportunities; learning is often regarded in terms of transfer between individuals, but also between individuals and organisations (examples are learning opportunities in clusters, companies, networks etc.) (Hassing \& Klaerding, 2012).

The importance of knowledge as a foundation for regional technological and social innovation and competitiveness, as discussed above, was early a topic of much interdisciplinary research (Al-Laham et al., 2011; Cotic-Svetina et al., 2008; Lawson \& Lorenz, 1998) mainly located in spatial science, social science, and economics. It is assumed that knowledge as coupled to humans, and foremost highly-skilled individuals, makes up the regional human capital, which constitutes a regional knowledge base. A broad knowledge base, which includes varieties of knowledge, can also positively impact the regional social capital of a region (Bourdieu, 1983). Social capital, as defined here, is the collective of existing current and potential resources given to a region and an individual (in Bourdieu's concept the spatial entity is not exactly defined as a region, but here his concept is translated to the regional entity). Along that line of thought, this article considers collective knowledge in the sense of codified knowledge, as a current and potential regional resource. Serageldin and Grootaert (2000) or Putnam (1993) define (social capital) resources as collective norms, networks and organisations. In this article actor networks, as part of social capital, are considered from this point of view as co-creators/coproducers of regional human capital strategies.

Different from "human capital", which obviously considers humans and their resources as capital, social capital can rather be described as any kind of relation between humans that is beneficial to the individual and the collective (Bourdieu, 1983). Thus, there is a certain codependence between human capital and social capital. The assumption is that the greater the 
percentage of a (highly) skilled workforce is in a region, which is interconnected by network relations and co-operation, the more it can positively affect the regional social capital. The correlation between human and social capital, can be explained as follows:

Human capital, which is the collective regional potential articulated in a human knowledge base and reflected in human labour and skills, is mostly linked to highly skilled, regarded as knowledge carriers. Regional social capital arises from the knowledge accumulated and exchanged by highly skilled in mutual co-operation. These co-operations often build networks. The scope of these networks can even reach transnational dimensions due to manifold interlinkages, which Granovetter (1973) calls weak and strong ties. These ties are helpful for new knowledge acquisition, knowledge generation, and knowledge exchange. Consequently, constituting and being part of such networks then mainly impacts on social capital, when the workers possess the ability to absorb the network-related knowledge. They can then spill it over to the regional knowledge base and transform it to regional needs. In that way, knowledge and actor networks become regional resources, which can be manifested regionally in new norms and organisations (Lawson \& Lorenz, 1998). Human capital may even become one of the regional sources, in terms of social capital, when (highly skilled) workers' knowledge is able to unfold regional effects to realise collective regional advantages and benefits.

Hereby, there is a huge potential in knowledge networks, which relate to re-migrants (Saxenian, 2007 calls them "New Argonauts") or "Expatriates" (Israel, 2006). Both groups are people who once lived in a region of their birth or who studied/worked there. They left the region for economic or social reasons and returned after a while. Return migration, as chapter 5 looks at more closely, is one of the key ways to provide regions with external knowledge. This can be explained by the fact that return migrants after an accomplished return migration still hold on to networks in both regions. In this way, they provide both regions with a brain exchange or brain circulation.

"In addition to acquired skills, employees who migrated for a while and re-turned also learn new social abilities. Often, they were active abroad in a different cultural environment and were part of a different society. They were handling different values and rules as they know from their home country or region and learn how to integrate themselves." (Dankwart \& David, 2011: 13).

According to the citation, highly -skilled workers, as regional human capital, constitute regional social capital by their interactions and knowledge. This happens not solely from their impact on regional economies, but also by their social abilities, which play out in social capital and regional attraction. A further beneficial side-effect of bridging social capital is explicitly drawn by actor networks as regional resources and their involvement in human capital strategies.

\section{RESEARCH QUESTIONS \& APPROACH}

To attempt to gain insights into and to understand the mechanisms underlying human capital strategies for highly-skilled immigrants and to fully unfold these strategies, the following research question was formulated:

What kinds of strategies take regions (including non-core regions) into consideration to assure an appropriate regional human capital stock, with a special focus on highly-skilled immigrants, for a sustainable regional economy and how do actor networks support this purpose?

This general research question was expanded with three sub-questions:

1. What kind of regional supportive concepts and actor networks facilitate brain exchange to promote knowledge spillover effects based on various migration patterns?

2. How do (university) alumni networks function as retention and (re)-attraction instruments for highly-skilled migrants? 
3. To what extent do migration networks influence the migration decision of highly-skilled graduates, and have migration motives changed over time?

4. How do R\&D policies, research infrastructure and regional economic networks impact on the development and recruitment of highly-skilled migrants?

In order to highlight the topic from different academic angles, several scientific disciplines have been incorporated, such as spatial (planning) science, social science, communication science, economics, and cultural science. The research focused on innovation and knowledge approaches, actor networks, firm and cluster theories, migration theories, and regional attraction models. The mixed-method approach includes qualitative and quantitative data based on previously accomplished surveys as well as conceptual approaches (Creswell \& Clark, 2011; Teddie \& Tashakkori, 2009).

The results presented here base on four different concepts and surveys to answer the four subquestions. The first one considered new migration flows and their possible knowledge spillover effects on regions and their economies. To deepen the understanding of how migration-related knowledge spillover effects can be fully used for regional concerns, two concepts were presented: regional inclusion and regional knowledge absorption.

The empirical material of the second survey was taken from the sub-project "BRAND - Border Regions Alumni Network Development", as part of the INTERREG IVC Mini Programme "Brain Flow". The unit of analysis here are university alumni networks in five European border regions: the Netherlands (NL), Germany (North Rhine-Westphalia) (NRW\&GER), Norway (NO), Sweden (SE), and Switzerland (CH). Here, their function as supportive instruments for the retention and (re)-attraction of highly-skilled immigrants is analysed. A standardized questionnaire addressed to alumni network managers was used in face-to-face interviews in the course of the in-depth case studies. Later, desk research was done on these networks. To gain further insight into what alumni networks do and how they are organised, a complementary web survey was added to the eleven alumni network case studies of the five European border regions. The web survey focused on the same countries: the Netherlands (NL), Germany (North Rhine-Westphalia) (NRW\&GER), Norway (NO), Sweden (SE), and Switzerland $(\mathrm{CH})$. but the web survey sample was taken from universities in all regions in these countries, not just the border regions. The web survey was deliberately confined to "traditional" universities rather than applied science universities because the status, size, scope and position of applied science universities varies considerably among the countries surveyed, leading to comparison difficulties. The sample for the web survey consisted of 47 university alumni networks, 14 from the Netherlands, 8 from NRW (Germany), 8 from Norway, 8 from Sweden, and 9 from Switzerland. It also looked into 38 faculty networks, 14 from the Netherlands, 14 from NRW (Germany), 3 from Sweden, and 7 from Switzerland. Because of the diversity and unbalanced country sample, the main focus of the web survey was applied in the overall university network; faculty network analysis was then used for comparison. The web survey provided less in-depth information on the scope and structure of the networks than with the case studies, which were based on face-to-face interviews and extended document analysis, even though the focus had been on the same questions and issues. The variables and analytic elements used for the web survey were taken from the explorative in-depth case studies.

The survey presented to answer the third sub-question deals with possible motives for migration which favour labour-driven migration. The views presented are those of a group of highly-skilled university graduates. The survey's empirical material is based on a standardised qualitative questionnaire distributed to Polish and German students shortly before graduation, 
as well as to graduates from public universities in two partner cities (Rzeszów, Poland and Bielefeld, Germany). The aim of the questionnaire was to discover how, based on the graduates' prospects, personal motives led to labour driven migration. The survey was conducted among university graduates, as well as students in their final semester in various disciplines, at the University of Bielefeld, the Bielefeld University of Applied Sciences, the University of Rzeszów, and the Rzeszów Technical University of Applied Sciences. A total of 439 participants from Bielefeld (Germany) and 402 from Rzeszów (Poland) took part. The groups of respondents were addressed with identical questionnaires, which dealt primarily with possible migration motives based on previous literature analysis. Thus, the majority of possible answers were given. Another part of the survey asked about the preferred destination countries of potential emigrants (in the case of possible migration). A further important requirement was to obtain insights into the question of which form of recruitment graduates wishing to migrate would choose. Would they prefer to use informal national networks or EUwide networks? This question was posed examine the idea of whether social networks are still important to those planning migrations and whether they are linked to job searches.

The fourth survey, a mixed-methods approach integrating quantitative and qualitative methodologies was applied to answer the last research sub-question. While the qualitative methodology was based on desk research including the analysis of secondary data plus semistructured interviews with cluster managers, the quantitative data were drawn from a company survey in the two case study regions Alsace/France-Comté (FR) and Stuttgart (DE), undertaken as part of the FP7 European funded project "ELMOs - Electromobility Solutions for Cities and Regions". The choice of case regions was made because of their strong automotive industry, their engagement in electric mobility, and localised clusters. The quantitative survey was based on a questionnaire that sought to develop insights into engineer recruitment practices by companies working on new transport and mobility solutions, as well as collaborative recruitment activities in the regions. It incorporated questions regarding companies' view on new driving technologies and future mobility concepts, demands for engineers in new mobility and transport solutions, and their perception of engineering education and its importance in relation to companies' demands plus future R\&D needs. Responses were measured using a 4-point Likert scale ranging from $1=$ 'I fully agree' to $4=$ 'I do not agree at all'. Administered by the cluster mangers in the two regions, the seven-page questionnaire was sent out to a sample of 1,000 companies active in electric mobility. Data were collected from the middle of March until the end of May 2014, including two reminders sent two and six weeks after the initial mail. In total, 79 valid questionnaires were received, representing a response rate of $7.9 \%$. In addition, a sample of 79 seemed adequate to determine significance at the $\mathrm{p}=0.05$ level, in order to emphasize possible existing differences or similarities between the regions regarding their regional orientation, personal regional contacts in their search for engineers, and the engineers' skills demanded.

All accomplished surveys had a strong focus on the identification and analysis of actors' networks and their role as attraction instruments for highly-skilled migrants. In the following a special section is given to the idea, following by the results.

\section{ACTOR NETWORKS AS CO-CREATORS AND CO-PRODUCERS OF REGIONAL HUMAN CAPITAL STRATEGIES}

\section{The Necessity of Regional Actor Network Involvement}

The overall argumentation of the article begins with the shift to knowledge-based societies and economies. As a result of this transformation, the perception of human capital changed and the demand for highly skilled workers as key knowledge carriers arose. For a long time, regions and their actors did not consider the attraction of highly skilled as a future challenge. For 
decades especially, the Western European regions possessed a stable and adequate stock of human capital. It was rather the Southeastern European regions that were hit by brain drain due to socio-economic factors and continuing migration outflows. In accordance with the challenges described at the beginning, European regions today have to face several obstacles in a search for highly skilled workers. These obstacles are the aging population, high unemployment rates related to the financial and economic crises, skills shortage, and several migration movements among (and to) European regions.

For a long time, Europe was assumed to be an attractive place in the world for highly skilled workers. This is accounted for by well-developed European industries, a large number of stable work places, sectoral diversity, a pool of globally popular firms and their headquarters, and good education systems in many European countries such as the UK, Germany, the Netherlands and others. All these factors impacted the European knowledge base, which today is lacking specific knowledge in some sectors. With the growing pressure on European regions and their economies to stay competitive in the globalised and digitalised world and due to the further economic development of countries such as China and India, or better migration policies provided by the U.S. or Canada (to name some examples), the attraction of European countries and their regions decreased in the perception of highly-skilled employees. Likewise, the attraction of Europe and its regions was adversely affected by the absence of concepts and strategies to permit highly-skilled immigrants to gain fast, uncomplicated entrance to the European labour markets and societies.

Furthermore, the economic crises of the past decade had an even greater impact on the regions' absence of awareness to develop and implement a sustainable regional human capital agenda, including strategies to mobilise, retain and (re)-attract a highly-skilled workforce. With the occurrence of the economic and financial crises, the European governments have focused more on the high unemployment rates and the supply of work opportunities for people with lower skills who were the first to be hit by the crises. Thus, for a long time highly-skilled (immigrant) workers were not on the national and regional policy agenda. By now, however, several European regions are claiming a great scarcity of highly-skilled workers and are experiencing brain drain. As described above, it takes some time for a policy process to recognise a problem (in this case the shortage of highly-skilled workers), to analyse it, to put in on the agenda, and to develop and implement top-down policies including measurements and strategies to tackle such a problem. In several regions, the demand for knowledge and highlyskilled immigrant workers reached a peak. As a reaction to these developments, many regions containing knowledge-based sectors and firms became active and developed bottom-up approaches. As presented in chapters 3-8, actor networks in several regions, as regional resource and part of the regional social capital, became proactive in human capital concerns. Primarily, the actor networks discussed in this study were set up for other reasons than as cocreators and co-producers of human capital strategies. Nevertheless, this article shows how existing actor networks respond as a side-effect, targeting a human capital problem and how they fill the gap left by the absence of top-down policies.

\section{Actor Networks as Regional Resources}

It was Bourdieu (1983) who first coined the term social capital. Only several years later did Coleman (1988) follow him in explicating the theory behind the term. To Bourdieu (1983: 248) social capital is "[...] the aggregate of the actual or potential resources which are linked to possession of a durable network of more or less institutionalized relationships of mutual acquaintance or recognition." Analogous to this definition, Coleman (1988: 98) refers to social capital as "[...] a variety of entities with two elements in common: They all consist of some aspect of social structures, and they facilitate certain actions of actors - whether personal or 
corporate actors - within the structure." Later on, Putnam (1993) as well as Serageldin and Grootaert (1997) considered social capital as potential and resources which play out in beneficial, collective and economic ways. As these benefits refer to collaborations between individuals and groups, such social actor networks have value (Putnam, 2000). The most recent definitions of Durlauf and Fafchamps (2004: 5) state, "[...] social capital is [...] networkbased processes that generate beneficial outcomes through norms and trust." Considering the previous definitions in retrospect, Durlauf and Fafchamps (2004) summarise the following aspects of social capital: (1) social capital generates positive external effects for members of a group, (2) these external effects are realized through shared trust, norms, and values and their consequent effects on expectations and behaviour, (3) shared trust, norms, and values result from informal forms of organizations based on social networks and associations.

Social capital can be considered according to its group/collective nature and its individual nature (Coleman 1990). By group-level social capital, Coleman (1990) and in line with him, Boshuizen (2009) define social capital as not being driven solely by individual interests and goals and independent actions, but rather as being bound by a social system that combines individual actions and interests to a whole social occurrence. By contrast, the individual nature of social capital is defined as "[...] the individual resource accessible via a social network of direct and indirect contacts" (Boshuizen, 2009: 29). In that line of thought, social capital is regarded as a ground for collective and individual beneficiaries of a region, which Putnam (2000: 319) claims "[...] where trust and social networks flourish, individuals, firms, neighborhoods, and even nations prosper." Based on Putnam's citation and the earlier definition of social capital as mirrored in networks built on trust and reciprocity (Boshuizen, 2009), here the actor networks are considered as social capital and assumes that:

Social capital forms the building blocks for the supporting actor networks that address the regional human capital problem with bottom-up strategies.

Actor networks are first of all social organisations (Cooke, 1996) that follow a specific dynamic and life cycle and are the link between independent actors of at least three equal member parties (Butzin, 2000). In addition, actor networks play an important role in, as they act towards clearly defined foci (Fürst \& Schubert, 1998), which here refers to the assurance of a "sustainable regional human capital stock". Moreover, these foci are addressed by horizontal communication structures without strong hierarchies. Likewise, actor networks are more flexible and faster in responding to socio-economic regional challenges than government organisations, which depend on strong hierarchies and long communication channels. Granovetter (1973: 1360) argues that networks show "[...] how interaction in small groups aggregates to form large-scale patterns [...]". For this reason, regionally based actor networks, which are founded on trust and reciprocity (Boshuizen, 2009), are based on shared norms and values and form part of the regional social capital, which can bring benefits to groups and individuals. In accordance with this, in the following examples of regional actor networks are described which were converted as supporting for the development and implementation of regional human capital strategies.

\section{Actor Networks - Bridging and Bonding by Weak and Strong Ties}

The consideration of regional actor networks as co-creators and co-producers of regional human capital strategies is based on the assumption that each network has a primary function and several secondary functions, which are regarded as the network's side-effect functions. For both the primary and the secondary functions, networks rely on weak and strong ties (Granovetter, 1973). Moreover, to emphasise the different interconnections between networks as part of regional social capital and to elaborate their benefits, in accordance with 
Granovetter's weak and strong ties, the bridging and bonding dimension of social capital (Putnam, 2000) is considered along the same lines.

As Burt (2005) explains, in any kind of network, it is not only direct connections, but also indirect connections that are of great importance. Both modes of interconnection form a network. Granovetter (1973) calls the different types of network connections "weak" and "strong" ties. In that sense, strong ties are the closest co-operations of a network. These are linear connections with high mutual confidence, reciprocal services, and a high emotional as well as temporal intensity. "Following this definition, a weak tie involves limited contact in time and intensity." (Boshuizen, 2009: 34). The assumption that strong ties provide a network with more information is misleading. It is these weak ties that deliver new information and knowledge to the network (members). This seems to be clear when one thinks about the fact that close friends and relationships as well as close network interrelations always move in the same actors' circle, where only a small number of new influences can be identified among the shared information. By contrast, weak ties, which consist of two separate components, can provide networks with new information flows and opportunities for development. Similar to Granovetter's (1973) concept of the "strength of weak ties", the social capital theory works with varieties of social capital called "bonds" and "bridges" (Putnam, 2000). Bonds are defined as links to actors in the sense of common identity. In line with Granovetter's strong ties, these are family members and close friends. In general, these are people who share the same culture, values and even ethnicity. Bridges, on the other hand, are links that sweep beyond the shared identity. These can be defined as distant friends, or second-hand relationships, colleagues and similar.

When translating the concepts of weak and strong ties as well as bonds and bridges to the actor networks as part of the social capital, one can state the following: each network has a primary function and a priority focus. Aside from this, networks may also have several sideeffect functions or activities which can be explored when required. For both the primary and secondary functions, strong ties are needed, such as regional bonds, but bridges and weak ties seem to be of even greater importance when redefining networks in accordance with their secondary functions or, as it has been termed, their side-effect activities. In addition, when decoupling networks from their function, but regarding them as ties (by themselves) in a brighter network structure, they can take on a double role. They can be bonds in the sense of strong ties in the region and bridges thanks to weak ties to the outside world. In that sense, the bridging function of a network's weak ties can be regarded as the opening of a region to external flows. These flows can be of knowledge and information and can deliver regions with innovative approaches and ideas. On the other hand, the bridging function of actor networks can offer equilibrium between the local and the global levels and quickly respond to any kind of challenges in a bottom-up problem solving approach.

The article shows how several networks are used as bridges and how their side-effect functions were used to develop and implement regional human capital strategies. In accordance actor networks are the objects of investigation here. The actor networks presented in this paper are described below. The further consideration of actor networks as co-creators and co-producers of human capital strategies can be found later on.

\section{MIGRATION NETWORKS}

Migration networks are social networks consisting of social ties between the domestic and the receiving country/region. Often, migration networks between two regions are established over the long term and date back to earlier times and historical interconnections between two regions (see as an example the Polish region Silesia and the German region North Rhine- 
Westphalia). Thus, many migration networks are path dependent. Because of the long term needed for their establishment, in their primary function they create social, financial (remittance) and human capital for both the domestic and the receiving region. In the case of preparation for migration, migration networks are often used to make the "proper" individual migration choice. They regularly function as a "door opener" in the receiving region by finding job opportunities for the "new" migrants or in helping them to integrate socially or setting up an immigrant entrepreneurship (David \& Coenen, 2017). A specific phenomenon of migration networks is transnational migration networks, which appeared with the phenomenon of "New Nomads" or "New Argonauts". Through the multilayer identity of the so-called transmigrants, transnational migration networks connect various actors from several regions and countries. They are used even more for economic concerns than traditional migration networks. Often such networks provide regions with knowledge exchange and innovative ideas, which can be adapted regionally. Diaspora networks, as a further category of migration networks, were in former times first and foremost related to migrants who had involuntarily left their domestic regions (e.g. refugees). Today, they help in forming the migrants' identity. In the case of highly skilled migration, migration networks, as side-effects, can function as a recruiter of highly skilled and platforms of knowledge generation and exchange between several regions.

\section{(HIGHER EDUCATION) ALUMNI NETWORKS}

Alumni networks are an old idea that originated in the USA at private higher education institutes. Mainly, alumni networks were significant in financial matters. Later on, the idea was translated to private higher education institutes and also found solid ground in further universities worldwide. Today, almost every university possesses its own alumni network. The concept of alumni networks refers to the motto: building a relationship with students not only for the years of study but rather for a lifetime brings lifelong benefits to both the university and the alumni. The primary goal of alumni networks focuses on the friendship and fundraising function in order to support the alma mater in maintaining its image, quality of studies, and its popularity and attractiveness to possible future students. In the context of human capital, alumni networks have been identified as possible co-creators and co-producers for the retention and (re)-attraction of highly-skilled migrants (David \& Coenen, 2014). This accounts for their ability to provide highly-skilled alumni with "warm city/place marketing" feelings in terms of knowledge and information exchange on the region. With regard to their retention strategies, many alumni networks offer career days and alumni days as information events. Moreover, field trips and labour market performances are used to try to bind graduates to the region and provide them with regional job opportunities. Concerning the (re)-attraction strategies, alumni networks organise homecoming events, send out job offers to their members, and arrange student and researcher exchanges.

\section{REGIONAL ECONOMIC NETWORKS}

Regional economic networks are described as "Triple and Quadruple Helix" constellations as well as policy and issue networks can be summarised under this umbrella cluster. Clusters are defined here as company networks in a certain sector, including companies along the entire value chain. One prior characteristic of clusters is their spatial proximity. Networks in the sense of a "Quadruple Helix" include university - industry - public co-operations and the civil society. Issue and policy networks are defined as regional actor networks that use a common regional frame to foster the more rapid development and implementation of regional policies related to a certain issue or topic. Regional economic networks are here regarded as part of the regional framework conditions, as described in the model of a regional human capital agenda. Regional economic networks, as their name reveals, are mainly built to strengthen regional economic concerns, such as innovation activities. As a side-effect, they can be used for human 
capital concerns by developing a regional framework where bottom-up strategies, which address human capital, can be developed and implemented.

\section{Spillover Effects Supported by Migration Networks}

\section{RESULTS FROM THE STUDIES}

The initial question based on the first survey asks:

What kind of regional supportive concepts and actor networks facilitate brain exchange to promote knowledge spillover effects based on various migration patterns?

Several concepts are known from the literature, which turn out to have a positive impact on the facilitation of brain exchange while at the same time promoting migration-related knowledge spillover effects. For instance, Klagge and Klein-Hitpaß (2010), Saxenian (2007), and Israel (2006) focus on the positive aspect of return migration in the form of brain exchange on regions. To make full use of the migrant knowledge spillover effects, Cassarino (2004) points to the importance of regional inclusion as a concept that has a positive influence on a successful migration process. He argues that the more "successful" a migration process is, the more benefits it can bring to both the domestic and the receiving region. The regional absorptive capacity described by Cohen and Levinthal (1990) suggests that the brighter a regional knowledge base is, the better and faster it can identify and absorb external knowledge to manifest it regionally.

The results of the first survey suggest that a better insight into the mechanisms of various migration patterns allows regions to create and use tailor-made concepts to facilitate brain exchange and knowledge spillover effects. In line with the literature, these concepts are recognised as inclusion and regional absorptive capacity. Inclusion aims to give the individual the feeling of being part of the regional society and in doing so, works with trust issues, which allow them to identify their specific skills and knowledge more quickly. These again can spill over into the region, given a well-developed knowledge base. A well-developed regional knowledge base, which works to support knowledge spillover effects, includes already allocated highly skilled workers and students, universities and advanced research organizations as well as knowledge-based sectors and firms. This collectively existing knowledge can better identify new knowledge and match it with the knowledge deficits of the region. This insight into migration-related knowledge flows is the starting point on which strategies can be developed.

Furthermore, the first survey discovered that the new forms of migration networks such as alumni networks, transnational migration networks, or new diaspora, could offer greater support to brain exchange. These actor networks, when addressing brain flow mechanisms, can influence the inclusion of immigrants with the attitude of a "welcoming culture" (door open function, job search function etc.). In addition, the named new migration networks are able to promote migration-related knowledge spillovers in two main ways: as knowledge generating and knowledge exchanging platforms, because these networks often provide a local buzz and act as global pipelines connecting the region through the actors involved to global flows and vice versa.

\section{Alumni Networks as Retention and (Re)-Attraction Instruments}

The initial question based on the second survey asks: How do (university) alumni networks function as retention and (re)-attraction instruments for highly-skilled migrants? 
Summarizing the findings of studies on alumni networks, which are higher education networks (such as university alumni networks), these are recognized as gaining in importance over the last several years (see for example Sá, 2010; Benneworth \& Hospers, 2007, Wolfe, 2005). Alumni networks are regarded as universities' (service) contacts. In the first instance the idea of alumni networks is based on alumni commitment to their alma mater by donating and/or associating. In return, alumni networks offer former students information on the universities' activities and help them to keep in touch. Moreover, they act as social networks based on mutual exchange and the organization of various events for the target groups. In doing so, alumni networks keep up contact with highly-skilled migrant, even when they leave the region. But even before that, alumni networks try to bind students to their alma mater during their study period. Alumni networks are a good example of networks that may co-create and coproduce human capital strategies, as a side-effect.

Another strand of the literature that takes account of the regional attraction perspective (cf. e.g. Hospers, 2010) argues, that (re)-attracting highly skilled migrants who already have ties to a specific region is much easier than attracting people who have never been in touch. Hospers (2010) calls this concept "warm city marketing". Considering the results of the literature review as a whole, it is clear that people who once lived in a specific region are easier to address than strangers to the region.

The results of survey 2 lead to the following conclusions. Personal regional networks such as alumni networks can be used as retention and (re)-attraction instruments for highly-skilled migrants, to facilitate their stay in the region and their return to the region. Alumni networks are able to provide a "warm feeling" (loaned from Hospers' concept of "warm city marketing") about the home region to the target groups, because personal relations are the direct linkage to a region. In the main, alumni networks take over the role of personal relations, when highly skilled toy with the idea of return migration after several years. Then, alumni networks, as part of the alma mater, are the first contact points for the returnees, when friends and colleagues are no longer located in the region.

Further results of the second survey are that alumni networks, as part of regional universities, can step into the retention and (re)-attraction function (which is not their primary function), when they use their communication channels not for university purposes only, but also for regional purposes. Moreover, they contribute to the retention and (re)-attraction of highlyskilled migrants when using the mutual exchange to provide their members with regional job opportunities and a regional welcoming culture. The outcome is that if alumni networks want to tackle their retention and (re)-attraction function, they should be more professional in the sense of organizational structure and staff, and look for closer co-operation with the university career centres, press offices or career counselling. In doing so, they can expand and accelerate their actions. Close links to regional stakeholders such as firms, chambers of commerce, regional agencies etc., can also increase the alumni networks' retention and (re)-attraction endeavours.

\section{Networks' Supported Migration Decisions of Highly Skilled Graduates}

The initial question based on the third survey asks:

To what extent do migration networks influence the migration decision of highly skilled graduates and have migration motives changed over time?

The broad literature on migration theories embraces the topic of migration networks. The literature on migration networks reviewed uncovered that these, including e.g. transnational networks and new diaspora, still come into action when a human takes the decision to leave 
the native country in order to migrate (compare for instance Castles et al., 2014; Pries, 2013). For instance, studies of Lee (1966), Castles et al. (2014) provide the information that main migration processes (excluding e.g. war refugees) are still strongly socio-economically motivated.

The results of survey 3 relate to this body of literature and show that the migration of highlyskilled graduates is still mainly motivated by socio-economic reasons, because there are labour market disequilibria and income differences and these refer also to the group of highly-skilled workers in Europe. In addition to the literature review, the clear-cut outcome of our own survey research is that highly-skilled graduate migration is not driven by income differences alone, as has been attributed to lower skilled migration processes. Further push-pull factors (see Lee, 1966) can be listed. Over time socio-economic migration motives also changed, because today's highly skilled graduates not only search for higher incomes, but also for appropriate career development and extended job opportunities within an international context (e.g. new language acquisition, transnational relations).

Migration networks and personal ties, such as new diaspora networks, alumni networks, and transnational migration networks, play an important role in job searching by highly skilled migrants in the receiving region and in the process of planning and accomplishing a migration, because many highly skilled graduates still rely on the first-hand experience of their predecessor. Therefore, such networks, which involve family, friends or colleagues', should be more focused if they are to be used as attraction instruments and knowledge spillover pipelines.

\section{Regional Economic Network Impact on the Recruitment of Highly Skilled Immigrants}

The initial question based on survey 4 asks:

How do R\&D policies, research infrastructure and regional economic networks impact on the development and recruitment of highly skilled migrants?

The literature on regional innovation capacity, like Chesbrough and Bongers (2014), and Dyer and Singh (1998), claim cross-organisational collaborations as the central success for company innovation. In line with that, Etzkowitz and Leydesdorff (2000) also name the "Triple Helix" or issue networks (Oermen, 2012) as a kind of policy network, which can act as additional tools for regions and their economies. With regard to human capital development, Tremblay (2006), for example, points to clusters as regional economic networks that play a pivotal role. This can be explained by the firms' proximity within a cluster and the industrial atmosphere contributing to employee skill development and learning effects. Additionally, Terstriep et al. (2014) argue that a decentral type of regional government structure including political frameworks has a positive impact on the development and establishment of regional R\&D policies, research infrastructure, and economic networks, which are the foundation for faster regional actions to respond to intra and inter-regional demands, such as the development and recruitment of highly skilled immigrant workers.

Based on a regional analysis, the findings of survey 4 show that governance structures organized decentrally can positively support regional R\&D policies, research infrastructure and regional economic networks. In doing so, these conditions can be developed more independently. Such a regional "atmosphere" fosters mutual actor co-operation and networks. These again can set their focus of action on regional points of interest such as the development and recruitment of regional human capital. This refers to the fact that decentralization leads to greater flexibility. This flexibility allows faster feedback and the faster development and implementation of regional bottom-up policies. These policies, then, are the umbrella under 
which strategies of e.g. actor networks and further co-operations can be formulated and realized in an accelerated process.

The fourth survey especially points to the role of clusters, as regional economic actor networks mainly regarded as policy or issue networks, in the process of further development and recruitment of highly skilled immigrant workers. This can be reduced to the fact that clusters usually are built as "Triple Helix" co-operations, where the exchange of information, knowledge, employees, and solutions is better organized among the partners and accords with the needs of regional sectors and firms. The short lines of communication and long-term cooperations within a cluster allow the partners involved to act quickly and more demandoriented.

\section{CONCLUSION AND RELEVANCE TO REGIONAL ACTORS}

The research reported here is relevant to regions in several ways. It has attempted to provide insights and to understand the mechanisms underlying human capital strategies with a special focus on highly-skilled immigrants. Several regional actors could support such a process, but actor networks, as a regional resource based on social capital, were considered as co-creators and co-producers of such strategies.

The following incentives are suggested for regional policy makers (regional governance including several actors' networks, higher-education institutes, firms and others).

First of all, this article provides insights into the topic of highly-skilled immigrant workers. It has revealed that human skills and potential do not depend solely on qualification levels and/or qualification degrees. A large number of employees have been identified as highly skilled because of their current working positions and the related skills. The potential of immigrants and return migrants has still not yet been fully uncovered. Policy makers and firms should aim at solutions to uncover these potentials. On the one hand, there is a need for the faster recognition of qualifications and degrees from abroad and inclusive approaches regarding individual migration biographies, in order to identify external knowledge, which is useful for regional purposes. During this process, it will be necessary to develop further qualifications for immigrant/re-migrant employees to quicker reach the national education level, in order to prepare them for (re)-inclusion into the labour markets. Firms with a high demand for highly skilled are asked to devoted more effort to "in-company training" or "vocational and advanced training" and trainings on immigrant entrepreneurship and entrepreneurial skills. Moreover, tacit knowledge, which is described as hard to translate into new setting, should command more attention from various regional actors, when talking about knowledge migration. Tacit knowledge maybe can be unfolding and communicated when cultural setting of receiving countries are similar to cultural settings of the domestic countries. This is a further argument, why it is of importance to consider migration biographies individually.

The research also provided that a special consideration may be given to the role of regional actor networks, which have been identified as a regional resource based on social capital for the co-creation and co-production of human capital strategies. Actor networks such as alumni networks, transnational migration networks, new diaspora, economic and issue networks can, under certain conditions, be used by regions for the retention and (re)-attraction of highly skilled migrants. With their bridging and bonding function (compare for instance Putnam, 2000; Coleman 1998) they act as a local buzz factor and a global pipeline at the same time and exchange human capital (e.g. return migrants), social capital (e.g. knowledge, information) and financial capital (e.g. remittances). A determination of regional responsibilities for the 
development and implementation of human capital strategies by actors allows regions to reach their goals faster and more efficiently, and avoids overlapping strategies.

The research reported here also argues that specific framework conditions such as a regional culture, a well-developed knowledge base and a good regional economic structure and a decentralised governance structure, facilitate the rise of human capital in terms of better external knowledge absorption, increased numbers of highly skilled workers, the creation of social capital, and actor networks. Based on this, the improvement of the regional knowledge base by the allocation of higher education institutes, the increase of regional R\&D activities, the number of students and graduates, as well as a mix of knowledge-based firms, helps regional actors to better identify new inflowing knowledge and match it with the regional needs to broaden the regional knowledge base. Thus, policy makers and universities should make efforts to attract students and knowledge-based companies from outside, in order to gain regional knowledge and provide highly-skilled (immigrant) workers with career development possibilities. For better absorption and usage of migration-related knowledge spillover effects, especially firms, in their position as employers, should consider migration processes and biographies more individually, and develop different concepts and strategies relevant to diverse migration patterns.

Finally, regions in general, but especially non-core regions, should not solely concentrate on symbolic capital creation, but rather on the creation of an appropriate economic structure including attractive career possibilities and working environments for highly skilled in general and specifically highly-skilled immigrants, which are flexible and which can use their full potential. Here policy-makers are asked to set up incentives that e.g. correlate with the lifecycles of highly skilled and provide them with benefits they will not find in other regions (escalator regions).

\section{References}

Al-Laham, A., Tzzbar, D. \& Amburgey, T. L. (2011): The Dynamics of Knowledge Stocks and Knowledge Flows: Innovation Consequences of Recruitment and Collaboration in Biotech. In: Industrial and Corporate Change, 20(2), 555-583.

Benneworth, P., Hospers, G-J. (2007): The New Economic Geography of Old Industrial Regions: Universities as Global/Local Pipelines. In: Environmental and Planning C: Government and Policy, 25(6), 779-802.

Bhabha, H. (2000): Die Verortung der Kultur. Stauffenburg Verlag, Tübingen.

Boshuizen, J. (2009): Join the Club! Knowledge Spillovers and the Influence of Social Networks on Firm Performance. University of Twente, CSTM.

Bourdieu, P. (1983): Ökonomisches Kapital - Kulturelles Kapital - Soziales Kapital. In: R. Kreckel (eds): Soziale Ungleichheiten, Soziale Welt Sonderband 2, Göttingen,183-198.

Butzin, B. (2000): Netzwerke, Kreative Milieus und Lernende Regionen: Perspektiven für die regionale Entwicklungsplanung? In: Zeitschrift für Wirtschaftsgeographie, 44, 3(4), 149-166.

Cassarino, J-P. (2004): Theorising Return Migration: The Conceptual Approach to Return Migrants Revisited. In: International Journal on Multicultural Societies IJMS, 6(2), 253-279.

Castles, S., De Haas, H. \& Miller, M. J. (2014): The Age of Migration: International Population Movements in the Modern World (5th Edition) Palgrave Macmillan, Basingstoke.

Chesbrough, H., Bogers, M. (2014): Explicating Open Innovation. Clarifying an Emerging Paradigm for Understanding Innovation. In: H. Chesbrough, W. Vanhaverbeke, J. West (eds): New Frontiers in Open Innovation, Oxford University Press, New York, 3-28.

Cohen, W.M., Levinthal, D.A. (1990): Absorptive Capacity: A New Perspective on Learning and Innovation. In: Administrative Science Quarterly, 35(1), Special Issue: Technology, Organizations, and Innovation, 128-152.

Coleman, J. S. (1988): Social Capital in the Creation of Human Capital. In: The American Journal of Sociology, Supplement: Organizations and Institutions: Sociological and Economic Approaches to the Analysis of Social Structure, 94, 95-120. 
Coleman, J. S. (1990): Foundation of Social Theory. Harvard University Press, Cambridge.

Cooke, P. (1996): The New Wave of Regional Innovation Networks: Analysis, Characteristics and Strategy. In: Small Business Economics, 8(2), 1-13.

Cotic-Svetina, A., Jaklic, M. \& Prodan, I. (2008): Does Collective Learning in Clusters Contribute to Innovation? In: Science and Public Policy, 35(5), 335-345.

Creswell, J.W., Clark, V.L. (2011): Designing and Conducting Mixed Methods Research (2nd Edition). Sage Publications, Thousand Oaks.

David, A., Evans, M., Hamburg, I., Terstriep, J. (2019) (eds.): Migration und Arbeit: Herausforderungen, Problemlagen und Gestaltungsinstrumente. Leverkusen: Verlag Barbara Budrich.

David, A., Barwińska-Małajowicz, A. (2018): Where Do We Go from Here? The EU Migration Flows After the Brexit Referendum: Possible Future Scenarios by the Polish Example. In: Journal of globalization studies 9, no. 2, p. 3-17.

David, A., Coenen, F. (2017): Immigrant Entrepreneurship - A Chance for Labour Market Integration of Refugees? In: David, Alexandra / Hamburg, Ileana (eds.): Entrepreneurship and Entrepreneurial Skills in Europe: Examples to Improve Potential Entrepreurial spirit. Opladen: Barbara Budrich, p. 77-101.

David, A. (2015): Scientia est potentia: Human Capital and the Role of Networks; Migration, Inclusion and New Qualification for a Austainable Regional Economy. ISBN 978-90-365-3981-4. Twente, Univ. Diss., 2015.

David, A., Coenen, F. (2014): Alumni Networks - An Untapped Potential to Gain and Retain Highly-Skilled Workers? In: Higher Education Studies, 4(5), 1-17.

David, A., Barwińska-Małajowicz, A. \& Coenen, F. (2012): From Brain Drain to Brain Exchange: How to Use Better Highly Skilled Workers; A Conceptual Approach. In: Unia Europejska.pl, 216(5), 25-35.

Dankwart, S., David, A. (2011): New Argonauts - A Concept for Regions. In: Working Paper, Institute of Work and Technology, Gelsenkirchen.

Drucker, P. (1969): Die Zukunft bewältigen - Aufgaben und Chancen im Zeitalter der Ungewißheit. Econ Verlag, Düsseldorf.

Durlauf, S. N., Fafchamps, M. (2004): Social Capital. Working Paper 10485. National Bureau of Economic Research, Cambridge.

Dyer, J. H., Singh, H. (1998): The Relational View: Cooperative Strategy and Sources of Interorganizational Competitive Advantage. In: Academy of Management Review, 23(3), 660-679.

Etzkowitz, H., Leydesdorff, L. (2000): The Dynamics of Innovation: From National System and "Mode 2" to a Triple Helix of University-Industry-Government Relations. In: Research Policy, 9(2), 109-123.

Faggian A., McCann, P. (2009): Human Capital, Graduate Migration and Innovation in British Regions. In: Cambridge Journal of Economics, 33(2), 317-333.

Fikkers, D. J. (2005): Regional Human Capital Policy Programs: Characteristics and the Hypothetical Influence of the Policy Theory. Hum paper presented at the Regional Growth Agendas Conference "Regional Studies Association", Aalborg, May 2005.

Florida, R. (2002): The Rise of the Creative Class. And How It's Transforming Work, Leisure, Community, and Everyday Life, Basic Books, New York.

Florida, R. (2008): Who's your city? How Creative Economy is Making where to Live the Most Important Decision of Your Life. Basic Books, New York.

Fürst D., Schubert H. (1998): Regionale Akteursnetzwerke. Zur Rolle von Netzwerken in regionalen Umstrukturierungsprozessen. In: Raumforschung und Raumordnung, 5(6), 352-361.

Granovetter, M. (1973): The Strength of the Weak Ties. In: The American Journal of Sociology, 78(6), 1360-1380.

Growe A., (2009): Knowledge-Holders and Networking in Metropolitan Regions. Spatial Requirements of Knowledge-Holders and the Combination of Politics. In: Raumforschung und Raumordnung, 5(6), 383-394.

Hassing, R., Klaerding, C. (2012): The End of the Learning Region as We Knew It; Towards Learning in Space. In: Regional Studies, 46(8), 1055-1066.

Hospers, G-J. (2010): Making Sense of Place: From Cold to Warm City Marketing. In: Journal of Place Management and Development, 3(3), 182-193.

Israel, N. (2006): Expatriates. Grundlagen, Auswahl, Erfolgsfaktoren. Saarbrücken: Vdm Verlag Dr. Müller. 
Klagge B., Klein-Hitpaß, K. (2010): High-Skilled Return Migration and Knowledge-Based Development in Poland. In: European Planning Studies, 18(10), 1632-1651.

Lawson, C., Lorenz, E. (1998): Collective Learning, Tacit Knowledge and Regional Innovative Capacity. In: Regional Studies, 33(4), 305-317.

Lee, E. S. (1966): A Theory of Migration. In: Demography, 5(1), 47-57; and in J. A. Jackson (eds): Migration, Cambridge University Press, Cambridge, 1969, 282-297.

Malmberg A., Power D. (2005): (How) do (Firms in) Clusters Create Knowledge? In: Industry and Innovation, 12 (4), 409-431.

Martin R., Sunley P. (2006): Path Dependence and Regional Economic Evolution. In: Journal of Economic Geography, 6(4), 395-437.

Mohr, H. (1997): Wissen als Humanressource. In: G. Clar, J. Doré \& H. Mohr (eds): Humankapital und Wissen Grundlagen einer nachhaltigen Entwicklung, Springer.

Oermen, J. (2012): The Issue Networks as a Deliberative Space: A Case Study of the Danish Asylum Issue on the Internet. In: CEU Political Science Journal, 7(1), 1-31.

Pries. L, (2001a): The Approach of Transnational Social Spaces: Responding to New Configurations of the Social and the Spatial. In: L. Pries (eds): New Transnational Social Spaces. International Migration and Transnational Companies in the Early Twenty-First Century, Routledge, London, 3-33.

Pries, L. (2013): Neue Dynamiken inter- und transnationaler Migration: Herausforderung für Wissenschaft und Politik. In: B. Pusch (eds): Transnationale Migration am Beispiel Deutschland und Türkei, Wiesbanden, 67-82.

Putnam, R. (1993): The Prosperous Community: Social Capital and Public Life. In: The American Prospect, 13, 1345.

Putnam, R. (2000): Bowling Alone: The Collapse and Revival of American Community, Simon and Schuster, New York.

Sá, C. M. (2010): Redefining University Roles in Regional Economies: A Case Study of University-Industry Relations and Academic Organization in Nanotechnology. In: Higher Education, 61, 193-208.

Salt, J. (1997): International Movements of the Highly-Skilled. OECD Social, Employment Employment and Migration Working, Papers, 3, OECD Publishing.

Saxenian, A. (2007): The New Argonauts: Regional Advantage in a Global Economy. Harvard University Press, Cambridge.

Serageldin, I., Grootaert, Ch. (2000): Defining Social Capital: An Integrating View. In: P. Dasgupta, I. Serageldin (eds): Social Capital: A Multifaceted Perspective, World Bank, Washington, D.C.

Smed Olsen, L., James, L. \& Dahlström, M. (2010): Knowledge Anchoring in European Regions: Policy Implications. In: H. Halkier, M. Dahlström, L. James, J. Manniche \& L. Smed Olsen (eds): Knowledge Dynamics, Regional Development and Public Policy, EURODITE Project (FP6) sponsored by the European Union, 2010.

Stockhorst J. (2011): Verfügbarkeit von hoch qualifizierten Arbeitskräften abseits der Ballungsräume, Regionale Restriktionen und Chancen für Hochtechnologieunternehmen der Medizintechnik, Stadt- und Regionalforschung. LIT Verlag Dr. W. Hopf, Berlin.

Teddie, Ch., Tashakkori, A. (2009): Foundations of Mixed Methods Research. Integrating Qualitative and Quantitative Approaches in the Social and Behavioral Sciences. Sage Publications, Thousand Oaks.

Terstriep, J., Lüthje, Ch. (2014): Do Clusters as Open Innovation Systems Enhance Firms' Innovation Performance? In: European Institute for Advanced Studies in Management: 19th International Product Development Management Conference: "Transformative Research in Product and Service Innovation", Manchester, U.K., June 18-19, 2012, The University of Manchester, Manchester Business School, 23, Manchester.

Tremblay, D.-G. (2006): Networking, Clusters and Human Capital Development. Canadian Policy Research Networks Inc., Montréal.

Trippl, M., Maier, G. (2007): Knowledge Spillover Agents and Regional Development. Working Paper of DYNREG Dynamic Regions in a Knowledge-Driven Global Economy Lessons and Policy Implications for the EU, Vienna.

Wolfe, D. A. (2005): The Role of Universities in Regional Development and Cluster Formation. In: G. A. Alan, P. L. McCarney \& M. L. Skolnik (eds): Creating Knowledge, Strengthening Nations: The Changing Role of Higher Education, 2005. 